Journal Of Agriculture and Social Research (JASR) Vol. 8, No.1, 2008

\title{
PARTICIPATORY SAVINGS AND BORROWING FOR START-UP AND RE- CAPITALIZATION NEEDS: FARMERS EXPERIENCE IN NIGERIAN AGRICULTURAL COOPERATIVES AND RURAL DEVELOPMENT BANK (NACRDB) ABIA STATE, NIGERIA.
}

\author{
EMEROLE , C.O; I. C. NWOSU, AND J. C. OLOJEDE
}

\begin{abstract}
This study of Farmer cash savers and borrowers was conducted in 5 branches of a formal small farmer-centered credit institution- the Nigerian Agricultural Cooperatives and Rural Development Bank $(N A C R D B)$ in Abia State, Nigeria. Thirty-two (32) farmers who had mandatory savings with the bank were involved. The savings rate across the branches averaged $8.33 \%$ but the borrowing rate was as high as $75.18 \%$ across the bank branches. A relatively higher proportion of the loans served re-capitalization purposes than start-up needs of the participants/beneficiaries .Experienced farmers with on-going projects were more prepared to manage credit facilities and should be considered for more loans whenever they meet up with the conditions for such new contracts.
\end{abstract}

\section{Key Words: Participation, Start-up needs, Re-capitalization needs.}

\section{INTRODUCTION}

One of the problems facing small-scale farmers in Nigeria is raising capital to start their business and/or sustain such started farm businesses(Odu,1996; Ukpong,1993). The savings and investment culture amongst this category of farmers who by far have remained collectively the main-stay of food production in the country (Dalhatu,1991), leaves much to be desired. Generating loanable funds and increasing investment in agriculture and other small-scale income generating activities remains part of the motives establishing the Nigerian Agricultural Cooperatives and Rural Development Bank (NACRDB). The commercial banks with the argument that giving loan to the many scattered small-scale farmers implies high transaction costs have remained reluctant in extending credit to this category of producers. Small farmers have had the options of borrowing from informal sources and/or from the NACRDB. While they do not save with most of the informal credit sources, it is the mandate of NACRDB to extend credit to farmers who have maintained savings deposit account with the Bank for a period of 60 days prior to a loan application ( NACRDB Brochure, Undated). This design according to de Negri et al. (1998) is a Participatory programme. It is a design that involves working in partnership with this target group (the farmers) to develop feasible, desirable, and sustainable programme. Savings and Borrowing are two complementary activities in a sustainable formal credit system, and therefore farmers requiring desirable functional credit source should be part of raising the funds (collectively in their small ways) and on their individual merits patronize such source(s) for meaningful farming investment .

Customer participation in creating the funds from which he/she borrows is a mechanism for collaboration and ultimately to empowerment. Participation as defined by The World Bank (1994) is a process through which stakeholders influence and share control over development initiatives, decisions and resources which affect them. Extending this idea, Rietbergen-McCracken and Narayan (1998) saw participation as a continuum which starts from information sharing to consultation, collaboration and empowerment. Taking farm credit from own banker gives a farmer sense of belonging and is one sure way of ensuring sustainable lending and borrowing among smallholder farmers.

This paper assesses the volume of savings and loans as well as their rates among smallholder farmers under the NACRDB scheme in Abia State. The much far this savings under the NACRDB credit scheme has helped in mobilizing funds amongst participating farmers was verified. 
The savings rate was compared in the state, with the lending rate of the Bank. From the perspective of the smallholder farmer's activities with the bank, these issues have been investigated as part of evaluation of the performance with respect to mandates and targets of the Bank in Abia state, Nigeria.

\section{METHODOLOGY}

Farmers saving and borrowing list at each branch was used as a frame to randomly sample participants in a survey of branches of NACRDB in Abia State. Thirty-two (32) farmers (Customers) were sampled in a proportion that reflects the Bank's categorization as A, B, and C branches. The Umuahia branch of the bank that is of category A covers 6 local Government Areas (LGAs), namely Umuahia North, Umuahia South, Ikwuano, Isiala - Ngwa North, Isiala - Ngwa South and Obingwa LGAs. Fifteen farmer-customers were selected from this branch. Obehie and Ohafia branches were of category B, and are serving 4 and 2 LGAs respectively. Obehie branch covers Osisioma, Ukwa East, Ukwa West and Ugwunagbo LGAs. Nine farmer-customers were chosen from this branch. The Ohafia branch covers Arochukwu and Ohafia LGAs. From this, branch four farmer-customers were selected. Isuochi and Akoli-Imenyi branches cover the three remaining LGAs. While Isuochi branch covers Umunneochi and part of Isuikwuato LGAs, the Akoli-Imenyi branch covers Bende and the remaining half of the Isuikwuato LGAs.

Two farmer-customers were chosen from each of the Isuochi and Akoli-Imenyi branches. All sampled farmers, and 15 bank officials directly concerned with administration of the loan (selected purposively, 3 from each branch) were interviewed with separate semistructured questionnaires designed for each category of respondents.

Savings and borrowing rates were calculated with the following credit formulae:

$$
\begin{aligned}
& \text { Savings Rate }=\frac{\text { Average Monthly Savings Deposits }}{\text { Annual Total Savings Deposits }} \times \frac{100}{1} \\
& \text { Borrowing Rate }=\frac{\text { Annual Total loan To Customers }}{\text { Annual Total loanable Allocation }} \quad x \quad \frac{100}{1}
\end{aligned}
$$

\section{Socio-economics of Farmer-Customers:}

Table 1.0 shows the socio-economic characteristics of farmer- customers who made cash savings, borrowed from NACRDB and who at the time of survey were operating their accounts at the various branches of the Bank in Abia State. 
Table 1.0 Percentage Distribution Farmer-Customers of NACRDB in Abia state,2005.

Measure $(\mathrm{n}=32)$

Age (Years):

$<29$

$30-49$

$50-69$

70 and above

Gender:

Male

Female

Marital Status:

Married $\quad 75.0$

Single $\quad 12.5$

Widowed

Divorced $\underset{\%}{\text { Percentage of Farmers }}$

3.1

43.8

50.0

3.1

75.0

25.0

12.5
9.4

3.1

50.0

46.9

3.1
Cumulative Relative

Frequency

3.1

46.9

96.9

100.0

75.0

100.0

75.0

87.5

96.9

100.0

50.0

96.9

$>10$

\section{Volume of Savings (N'000):}

10-29

85.3

85.3

30 - 49

11.8

97.1

50 and above

2.9

100.0

Source: Field Survey, 2005.

The Table shows that more than half of the farmer- customers were at least 50 years of age suggesting that elderly and experienced farmers were committed to the business of savings to qualify for loans. More male farmers $(75.0 \%)$ were financing the farms through formal leverage than females $(25.0 \%)$. Half the number of the farmer-customers had households of less than six inmates. Majority $(85.3 \%)$ of the farmer-customers saved between ten and twenty-nine thousand naira. This confirms the smallness of their farm sizes. This small volume of savings largely determines the volume of credit such customers can apply for from the bank as balances in the accounts should show minimum of $10 \%$ of the loan amount applied for. In addition, the savings account should grow during the period of the loan. The bank has limited sources of loan able funds. In addition to their shares of loanable funds provided by the owner (the Government of the Federal Republic of Nigeria- through Federal Ministry of Finance and the Central Bank of Nigeria) and project - targeted funds from International financial bodies, the NACRDB inflow of re-cycling cash came from customer savings deposits.

\section{Savings And Borrowing Rates:}

Each branch of the Bank had yearly target of loanable amount and lent to her customers within the targeted amounts. The rates of savings and borrowing observed are computed and shown in Table 2.0. The annual total loanable allocation to the bank in 2004 amounted to 86 million. The annual total loan given to customers in the state was $\$ 64.66$ million, with a total customer savings deposit of $¥ 25.9$ million over the period.

These amounts are small relative to the gap in demand for loans from this Bank in the state. Loan demands are activities initiated internally amongst the farm households each of which strives to take advantage of institutional funds to better their economic status through enhanced crops and 
livestock production. Farmers demand for loan in the state from this bank outstrips supply of loan able funds as earlier observed ( Emerole, 1995). Serious unmet demands of institutional credit has forced business-minded farmers to resort to private sources of funding, many of which have their shortcomings. These they must tolerate since it is important that realistic start-up costs and running costs be offset to effectively and productively conclude production cycles.

Table 2. 0 Savings and Borrowing Rates In NACRDB Branches in Abia State,2004.

Variable

Average Monthly Savings Deposits ( N’000)

Annual Total Savings Deposits ( N’000)

Savings Rate (\%)

Annual Total Loan To Customers ( N'000)

Annual Total Loanable Allocation ( N'000)

Borrowing Rate (\%)

Source: Field Survey, 2005.
Savings

$2,162.49$

$25,949.92$

8.33
Borrowing

$64,656.00$

$86,000.00$

75.18

The average savings rate by customers of NACRDB in Abia state in 2004 was $8.33 \%$ whereas the average borrowing rate by the same customers was $75.18 \%$ over the period. This disparity in the rates suggests that for the Bank to meet up with her expectations of providing enough agricultural loans for farming, strong external financiers must complement the efforts of its present owners. In addition, small farmers, and other Small and Medium Scale Enterprises (SMEs) whose operations are within the mandate of the Bank and are currently patronizing the bank should be committed to their savings obligation with utmost business passion for optimum achievements.

\section{Customer Savings Motive With The Bank:}

Farmers saving with the NACRDB did so to borrow either for financing new enterprise(s) or recapitalizing the existing ones. The activities, which covered many enterprises in crops and livestock sectors were carried by farmers under in this lending reforms of the bank across the state. Patronage of beneficiaries was on going at the time of this investigation and their motives for the loans are summarized in Table 3.0. The primary aim of the savings was to qualify for investment loans.

Table 3.0 Farmers Motives For Saving/Borrowing In Abia State, Nigeria.

Banking Activity $\quad$ Intending Motive

Enterprise Start-Up Re-capitalizing Enterprise

Saving with NACRDB $\quad 9(28.13) \quad 23(71.87)$

Borrowed from NACRDB $11(34.38) \quad 21(65.63)$

\section{Source: Field Survey, 2005; Figures in brackets are row Percentages.}

Table 3.0 shows that more than half of the participating farmers saved with, and borrowed from NACRDB for the sake of re-capitalizing their existing farm enterprises. While 71.87 Percent of the farmers complied with the requisite savings mandate, 65.63 percent of them benefited from the loan facilities. This suggests commitment of the Bank in the savings and loans scheme under the new dispensation to participating farmers who have adopted new business approaches in their 
occupational pursuit. To attract more profits in farm business, a strong capital base is needed in place by the entrepreneurs to guarantee timely access to funds needed for buying equipment, restocking, paying for labour, utilities, transportation, raw materials and other developmental needs of their farms.

Participatory action - oriented move in the management of credit to rural farmhouseholds in the state have drawn more from existing custom and cultural pattern, of the people capturing attachment and dedication of the farmers to the scheme. With this, the obvious problem of default in loan repayments (Njoku and Odii,1991; Mijindadi and Otu,1985) would have been taken care of. This anticipation is based on the fact that only true (experienced) farmers who would not divert the loans received the credit facilities and are applying them judiciously in improved, yield/product - increasing agricultural technologies. Farmers for the start - up loans might have been persons who have decided to be guided by expert advice.

\section{CONCLUSION/POLICY ISSUES}

Farmers are participating in the savings and loan schemes of the NACRDB in the five branches of the Bank in Abia State, Nigeria. The Bank apparently was committed to granting loans to farmers and operators of Small and Medium scale business enterprises who saved and were sustaining their savings with them. The volume of credit such customers obtained from the bank depended on their personal amount of savings, as the balance to the account of such customers must show minimum of $10 \%$ of the loan amount they applied and were favourably considered for.

Most of the farmer beneficiaries of the loan were young, married males, with some farming experiences and some good level of literacy. Male dominance in farm capital formation and financing suggests that many women in the state were serving as mere farm hands than as entrepreneurs. Farm resource mobilization and distribution can be made efficient by balancing gender in a reasonable credit allocation/delivery system. The savings rate across the branches averaged $8.33 \%$ but borrowing rate was as high as $78.15 \%$. A relatively higher proportion of the loans served re-capitalization purposes than start-up needs, as the many experienced farmers borrowed to fund their on-going enterprises.

The participating farmers should have been genuinely committed and were therefore encouraged by the bank to save more to qualify for bigger amounts of money as loans. Bigger sums received as loan should be motivator to the recipient in increasing not only level of improved input usage, but enhance level of farm productivity and farm income.

\section{REFERENCES}

Dalhatu, M.B.(1991). Chairman's Remarks. Annual Reports and Statement of Accounts. Nigerian Agricultural Cooperatives Bank Limited.Kaduna.

Brochure, (Undated). Nigerian Agricultural Cooperatives And Rural Development Bank Limited. The corporate Affairs Department, Office of the Managing Director/ Chief Executive Officer, NACRDB Kaduna p. 52.

Emerole, C.O.(1995). Demand For Institutional Credit By Farmers in Abia state, Nigeria: A Case Study of The Nigerian Agricultural and Cooperative Bank Limited. Unpublished M.Sc. Thesis; Department of Agricultural Economics and Extension, Federal University of Technology Owerri, Nigeria.

Mijindadi, N.B and Otu, M.F. (1985). Factors that Determine Credit Repayment of Cooperative Societies in Nigeria. A Case study of Kaduna State Cooperatives. Paper presented at the National Workshop on cooperatives for Policy makers. ARMTI in Ilorin, April 29- $1^{\text {st }}$ May. 
Njoku, J.E and Odii, M.A.C.A (1991). Determinants of Loan Repayment Under The Special Emergency Loan Scheme (SEALS) in Nigeria: A Case Study of Imo State. African Review of Money, Finance and Banking No.1 p.39- 52, FinAfrica Cariplo, Milano.

Odu, P.C. (1996). Problems and Prospects In Agricultural Financing In Nigeria Under Economic Deregulation. Agricultural Finance Department; Central Bank of Nigeria, Bullion 20:3 3148.

Rietbergen- McCracken, J and Narayan, D. (1998). Participation and Social Assessment: Tools and Techniques. IBRD and The World Bank, Washington, D.C. USA.

The World Bank (1994). The World Bank and Participation. Operations Policy Department, Washington, D.C. USA.

Ukpong, G.E. (1993). Some Strategies For The Development of Nigeria's Agricultural Sector in the 1990s. Economic and Financial Review. C.B.N, Lagos. 